\title{
UNIVERZÁLNOSŤ I JEDINEČNOSŤ PALÁRIKOVHO DIELA INKOGNITO V KONTEXTE FORMOVANIA SRBSKÉHO NÁRODNÉHO DIVADLA
}

Činnost' i umelecké dielo slovenského katolíckeho kňaza, redaktora, dramatika a organizátora spoločenského a politického života Jána Palárika presiahli v druhej polovici 19. storočia horizont habsburskej monarchie. Literárne i spoločensko-politické stopy Palárikových aktivít nachádzame aj medzi Srbmi žijúcimi v Budapešti, ktorí si Palárikovu veselohru Inkognito vybrali v roku 1861 ako jednu z možností na získanie prostriedkov pre fungovanie práve vznikajúceho Srbského národného divadla v Novom Sade. Navyše, hra našla svoje miesto aj na srbských javiskách a jej nosné myšlienky postupne prenikali medzi Slovanov na Balkáne. Uhorský vlastenec a slovenský národovec prekročil prostredie, z ktorého vyšiel a nasledovníkom zanechal výrazný odkaz na poli organizovania národného a literárneho života, dramatického umenia a demokratizačných reforiem $\mathrm{v}$ cirkvi.

Klúčové slová: katolícky kňaz a dramatik Ján Palárik, veselohra Inkognito, uvedenie hry Inkognito v Budapešti srbskými ochotníkmi, Srbské národné divadlo v Novom Sade, slovanská vzájomnost'.

The activities and artwork of the Slovak Catholic priest, editor, playwright and organizer of the societal and political life Ján Palárik exceeded the horizon of the Habsburg Monarchy in the second half of the $19^{\text {th }}$ century. Literary and socio-political traces of Palárik's activities can also be found among the Serbs living in Budapest, who chose Palárik's comedy Inkognito in 1861 as one of the options for obtaining funds for the functioning of the newly emerging Serbian National Theater in Novi Sad. In addition, the play found its place on the Serbian stages and its main ideas gradually spread among the Slavs in the Balkans. The Hungarian patriot and supporter of Slovak identity surpassed the environment from which he emerged and left his followers a strong message in the field of organizing national and literary life, dramatic art and democratization reforms in the church.

Keywords: Catholic priest and playwright Ján Palárik, comedy Incognito, launch of Incognito in Budapest by Serbian amateurs, Serbian National Theater in Novi Sad, Slavic mutuality.

Všestrannost' a zároveň jedinečnost' literárneho diela a spletité životné cesty Jána Palárika (1822 - 1870) otvárajú viaceré možnosti skúmania tejto osobitej postavy slovenskej literatúry, kultúry i politiky. Palárikove aktivity obsiahli rozmanité aspekty spoločenského a verejného života - výrazná spolková a editorská činnost', politická angažovanost', duchovná služba, otváranie ekumenického dialógu omnoho skôr, než bola táto téma výraznejšie prítomná v slovenskej spoločnosti, a v neposlednom rade zjavná zásluha $\mathrm{v}$ rámci slovenskej dramatickej literatúry - v spomínaných oblastiach sa Palárik angažoval do posledných síl, s absolútnym nasadením a neochvejnou vierou, že jeho pokrokové a liberálne zmýšl'anie a hlásanie náboženskej a národnostnej tolerancie môže stát' na začiatku zmien v slovenskej politike a spoločnosti. Uhorský vlastenec a slovenský národovec vel'kými krokmi prekročil prostredie, z ktorého vy- 
šiel a nasledovníkom zanechal výrazný odkaz na poli organizovania národného a literárneho života, dramatického umenia a demokratizačných reforiem v cirkvi.

\section{Ján Palárik - kaplán, redaktor, literát a dramatik}

Náklonnost' k literatúre, hudbe a spevu si z domáceho prostredia Palárik odniesol na stredoškolské štúdia do Žiliny a Kečkemétu, neskôr ju rozvíjal aj na teológii v Ostrihome, Bratislave a Trnave. V trnavskom biskupskom seminári spolu s Jozefom Viktorinom $^{1}$, Martinom Hattalom ${ }^{2}$, Jánom Gotčárom ${ }^{3}$ a grófom Rudolfom Nyárym ${ }^{4}$ vytvorili krúžok národne uvedomelých, liberálne orientovaných seminaristov, s ciel'om stat' sa „apoštolami pravdy slovenskej“ (Bobula 1871: 503) a zdokonal'ovat' sa v literatúre, filozofii a v štúdiu jazykov. V seminári sa Palárik nadchol básnickým dielom Jána Hollého a začal čítat' almanach Zora, čo v ňom značne prebúdzalo národné povedomie. Práve obdobie seminárnych rokov je vel'mi dôležité pre l'udské i duchovné dozrievanie Palárika národovca, literáta i politika. V seminári sa venoval podrobnejšiemu štúdiu cudzích jazykov, ${ }^{5}$ zoznamoval sa s dielami encyklopedistov a horlivo čítal hry francúzskych a nemeckých dramatikov. ${ }^{6}$ Otvorenosti Palárikovho

${ }^{1}$ Jozef Karol Viktorin $(1822$ - 1874) - slovenský katolícky kňaz, vydavatel' slovenskej literatúry, organizátor kultúrneho života a publicista; po štúdiu v trnavskom biskupskom seminári bol v roku 1847 vysvätený za kňaza; ako kaplán pôsobil v Senici, Trstíne, Skalici, v Starom Budíne a od roku 1866 bol farárom vo Vyšehrade (mad’arský Visegrád).

${ }^{2}$ Martin Hattala (1821 - 1903) - jazykovedec, univerzitný profesor, kodifikátor etymologického pravopisu, autor modernej slovenskej gramatiky Krátka mluvnica slovenská (1852); po štúdiách v Trnave sa dostal na viedenské Pazmaneum a v roku 1848 ho v Ostrihome vysvätili; ako kaplán pôsobil v Bzovíku pri Krupine a v Hodruši; v roku 1850 získal učitel'ské miesto na gymnáziu v Bratislave; od roku 1854 prednášal na univerzite v Prahe.

3 Ján Gotčár (1823 - 1883) - katolícky kňaz, národnokultúrny a školský pracovník, pedagóg a publicista; v roku 1846 vysvätený za kňaza; ako kňaz pôsobil v Pešti, kde spolupracoval so slovenskými vysokoškolákmi; v rokoch 1848 - 1856 bol učitel’om na gymnáziu v Banskej Bystrici; v rokoch 1858 - 1867 pôsobil ako školský radca a hlavný dozorca škôl v Oradei (Rumunsko); podiel'al sa na založení Matice slovenskej a spoluzakladal slovenské katolícke gymnázium v Kláštore pod Znievom.

${ }^{4}$ Rudolf Nyáry (1828 - 1900) - ostrihomský kanonik a spisovatel' duchovnej literatúry; po štúdiách teológie a filozofie v trnavskom seminári bol v roku 1851 vysvätený za kňaza; ako kňaz pôsobil na dvore kniežat’a Scitovszkého; v roku 1864 sa stal ostrihomským kanonikom.

${ }^{5}$ Znalost' pol’štiny a češtiny si priniesol Palárik z domova, mad’arčinu a nemčinu sa naučil počas stredoškolských štúdií a latinčinu, gréčtinu, francúzštinu a ruštinu sa naučil a zdokonalil v seminári.

${ }^{6} \mathrm{O}$ Palárikovom pôsobení v trnavskom seminári bližšie pozri štúdiu Za osvetu (1871) Jána Nepomuka Bobulu uverejnenú v diele Sobrané dramatické spisy Jána Palárika, (Beskydova) slavného spisovatel'a slovenského (Bobula 1871). Akciová spoločnost' Minerva - prvá uhorsko-slovenská kníhtlačiareň a vydavatel'stvo - vydala v rokoch 1870 - 1871 texty Jána Palárika v dvoch zväzkoch ako zobrané dielo doplnené textom Za osvetu Jána Nepomuka Bobulu, v ktorom autor približuje životné osudy Jána Palárika. Ciel'om vydavatel'stva a tlačiarne Minerva bolo podporovat' zbližovanie slovenského a mad'arského obyvatel'stva skíbením národných a hospodárskych ciel'ov a vydávat' slovenskú a mad’arskú literatúru. Len pre zaujímavost' a ako príklad hlbokých slovanských vzt’ahov a nepretržitej a intenzívnej spolupráce dodáme, že zobrané dramatické spisy Jána Palárika venovali členovia vydavatel'stva chorvátskemu biskupovi Josipovi Jurajovi Strossmyyerovi, čo dokladá venovanie na predsádke knihy: „Osvietenému mužu, vysokoctenému a váženému pánu Josipu Jurju Strossmayeru, diakovárskemu biskupu (...) zastavetel’ovi práv národních, horlivému a srdeč- 
ducha bolo blízke chápanie zásad osvieteneckej vedy - kritickost' a dôvera v rozumové poznanie. Nepochybne ho udivoval a fascinoval jedinečný a ambiciózny sumár dovtedajšieho poznania, ktorý mu otváral nové pohl'ady na fungovanie dobovej spoločnosti. V prepájaní filozofie, morálky a poznania bolo pre Palárika nadmieru inšpiratívne dielo pražského univerzitného profesora Bernarda Bolzana, ktorý sa stal vzorom pre mladých klerikov najmä tým, ako dokázal zosúladit' konkrétny vedecký záujem s ušlachtilou l’udskou a mravnou autoritou. Blízka mu bola aj Bolzanova idea, podl'a ktorej viera nezbavuje človeka povinnosti používat' vlastný rozum a naopak. Odvahu slobodne sa vyjadrovat', kriticky a nezaujate mysliet' a tiež správne argumentovat' získaval Palárik práve pod dojmom z diel Bolzana, Thomasa Hobbsa či Adama Smitha. Z filozofických spisov ho zaujal najmä traktát Duch zákonov (1748) Charlesa de Montesquieua, ktorý „detailne poznal a pri rôznych vlastných článkoch ho neraz aj citoval" (Timko 2017: 8), pretože ho považoval za priekopnícke dielo v oblasti komparatívneho práva a oslovili ho najmä podoby spoločenského zriadenia a politické správanie l'udí v rôznych spoločnostiach, čo neskôr opísal v literárno-politickej úvahe $O$ vzájomnosti slovanskej (1864) ${ }^{7}$.

Teologické štúdiá ukončil Palárik v roku 1847, za kňaza ho vysvätili v Ostrihome a poslali do Starého Tekova za kaplána. Revolučné roky 1848 - 1849 prežil v Tekove, kde mal vo farnosti na starosti duchovné a náboženské potreby obyvatel'ov vo filiálkach, teda vo Vel'kých Kozmálovciach a Hronských Kl'ačanoch. Počas druhej dobrovol'níckej výpravy sa v januári až apríli 1849 schovával na fare v Starom Tekove u Palárika pol'ský generál Josef Wysocki (1809 - 1873), s ktorým Palárik viedol intenzívne rozhovory o národných veciach, revolúcii i slovanskej vzájomnosti a tento pobyt významne prispel k upevneniu Palárikových sympatií k Poliakom. Ako kaplán burcoval veriacich za národné veci a usiloval sa ich viest' $\mathrm{k}$ vzdelaniu a miernosti v požívaní alkoholu, uvedomujúc si ako tento neduh ničí človeka i celé rodiny (v

nému priatel'ovi umenia, vedy a literatúry, velikodušnému podporovatel'ovi podnikov národa slovenského." Viac než priatel'ské vzt’ahy medzi Jánom Nepomukom Bobulom, slovenským podnikatel'om, vydavatel'om a politikom (spoluzakladatel' Novej školy slovenskej) a djakovským biskupom Strossmayerom potvrdzuje aj skutočnost', že chorvátsky biskup Strossmayer bol krstným otcom najstaršieho Bobulovho syna Jána, narodeného v roku 1871. Podrobne Bobula 1870.

${ }^{7} \mathrm{~V}$ stati $O$ vzájomnosti slovanskej Palárik otvorene charakterizoval slovanskú spoluprácu nielen na úrovni kultúrnej a spoločenskej, ale venoval sa tejto problematike v rámci spoločných politických požiadaviek - zákonne garantovat' rovnoprávnost' a slobodný (politický) vývin slovanských národov. Štátom podporovanú asimilačnú politiku Palárik odmieta a ako alternatívu navrhuje spoluprácu národov žijúcich v Uhorsku, lebo každý národ v monarchii má prirodzené a historické právo na rovnost's tými ostatnými. Jednotlivé národy Uhorska videl Palárik usporiadané do federatívneho zväzku, silného štátu s rovnoprávnost'ou jednotlivých národností: „Naproti tomu velikánsky národ slovanský už mocou svojho rozvetvenia na rozličné vyvinuté kmene pravdepodobne nie k centralizácii, ale najvýš k federácii smeruje, a práve preto on jedine zdá sa byt' povolaný rovnoprávnost' a slobodu národov v Európe zachránit' a ustálit'. A v tomto spočíva vel'kost' a vznešenost' historickej úlohy, ktorú Slovania v dejinách človečenstva vykonat' majú.“ Palárik bol proti založeniu vel'kej ,,všeslovanskej ríšse“, jeho ciel'om bolo vytvorit’ štát, v ktorom by každý kmeň mal svoju vlastnú vládu: „(...) každý jednotlivý kmeň slovanský odvodit’ si môže spôsob politiky, akú má sledovat'. Každá politika, ktorá protiví sa týmto zásadám, je podl'a môjho náhl’adu neslovanská, nenárodná." Palárikova úvaha o novom politickom usporiadaní monarchie bola návrhom na necentralistickú, federalistickú a demokratickú reformu slovanstva. Celá úvaha pod názvom $O$ vzájomnosti slovanskej bola publikovaná v roku 1864 v almanachu Lipa III (Palárik 2012). 
Starom Tekove založil Spolok striezlivosti). V januári 1850 preložili Palárika za kaplána do Vindšachtu (Štiavnické Bane), kde sa okrem kňazskej pastoračnej činnosti venoval aj redaktorskej práci v prvom po slovensky písanom cirkevnom časopise Cyrill a Method $^{8}$, ciel'om ktorého bolo okrem iného rozvíjat' a pestovat' cyrilo-metodskú tradíciu, budovat' kontakty so slovanským svetom a publikovat' umelecké texty. $\mathrm{Na}$ stránkach časopisu uverejňoval Palárik názory na reformu v cirkvi, žiadajúc vytvorenie slovenského arcibiskupstva v Nitre alebo v Trnave, nové usporiadanie diecéz a cirkevného majetku, novú hierarchizáciu (všetko na základe národnej rovnoprávnosti) a presadzoval myšlienku zjednotenia katolíkov s evanjelikmi ${ }^{9}$. Ekumenické názory vyjadril aj umelecky v básňach Cirkev Kristova (1850) a Jednota w Církwi (1850), v ktorých hovorí o potrebe a dôležitosti jednoty vo všetkých rovinách života človeka: „Nech že je aj w národě / Jeden zákon roztomilý! / Národa - neshoda, / Najwětší jest škoda: / Protož nech nás mysel jedna / a nábožný jeden cit / Opanuje, jináč bídná / Wlast' slowanská musí byt'. / Jeden duch je swěta w dějstwu. / Nech že je aj w člowěčenstwu!“ (Palárik 1850). Ostrihomské arcibiskupstvo a biskupský zbor Palárik vyzýval, aby boli v uhorských seminároch zriadené katedry slovenskej reči a literatúry pre výchovu kňazského dorastu, ktorý bude v budúcnosti pôsobit' medzi slovenským národom. Reakcie na Palárikovo ekumenické posolstvo a kritiku pomerov vo vnútri cirkvi nenechali na seba dlho čakat'. Za presadzovanie ekumenizmu a demokratizačných reforiem v cirkvi prišiel trest v podobe cirkevného väzenia a následné preloženie. V roku 1851 vidíme už Palárika vo Farnosti sv. Terézie v Budapešti, ktorá zabezpečovala ,duchovné úkony pre jednotlivé národnosti žijúce v predmestí: Nemcov, Mad’arov a Slovákov“ (Kačírek 2016: 133), a tak Palárik na seba prebral starostlivost' o slovenských veriacich farnosti a k jeho povinnostiam, okrem cirkevných, patrila aj výučba náboženstva na školách. ${ }^{10}$

Desat'ročie strávené v Budapešti otvorilo Palárikovi cestu k bohatej literárnej tvorbe, prekladom, redaktorskej, spolkovej a verejnej činnosti. V rokoch 1852 - 1856 redigoval Katolícke noviny, v slovenskom preklade vydával Spisy pre mládež Kristofa Schmida, spolu s Andrejom Radlinským ${ }^{11}$ a Jozefom Karolom Viktorinom ${ }^{12}$ organi-

${ }^{8}$ Časopis Cyrill a Method začal vychádzat' ako týždenník 14. marca 1850 a vydával ho Andrej Radlinský v Banskej Štiavnici. Redaktorom bol Ján Palárik. V roku 1857 došlo k zlúčeniu časopisu s Katolickymi novinami a vychádzal pod názvom Cyrill a Method, Katolické Noviny pre Cirkev, Dom a Školu.

${ }^{9}$ Už počas seminárnych čias Palárik bytostne vnímal, že príčinou chabej energie v boji za národné myšlienky je predovšetkým náboženské rozdelenie Slovákov na katolíkov a evanjelikov. Ekumenické myslenie Jána Palárika vyrastalo z poznania slovenskej reality i poznania situácie ostatných slovanských národov.

${ }^{10}$ Vo Farnosti sv. Terézie v Budapešti pôsobil Palárik od 1. júla 1851 do 6. decembra 1862. Nahradil kaplána Karola Sladkého, ktorý sa stal kaplánom pluku. Podrobne o pôsobení Jána Palárika vo Farnosti sv. Terézie v Budapešti pozri Kačírek 2016: 130-136.

${ }^{11}$ Andrej Radlinský (1817 - 1879) - slovenský katolícky kňaz, jazykovedec, pedagóg, vydavatel'; zakladatel' Spolku svätého Vojtecha a spoluzakladatel' Matice slovenskej; v rokoch 1849 1861 pôsobil v Budíne ako redaktor českej osnovy Zemského zákonníka.

${ }^{12}$ V apríli 1852 preložili Viktorina zo Skalice do Starého Budína, kde pôsobil ako kaplán a neskôr sa stal administrátorom farnosti. Od roku 1856 bol kaplánom vo Farnosti sv. Anny v Budíne, kde zostal do roku 1866, ked' odišiel do Vyšehradu (Visegrád), aby tu prijal miesto farára. 
zoval zbierku na náhrobný kameň Jána Hollého, sústred’oval sa na vydávanie diel pre dospelých i mládež ako aj na vychovávanie mladej generácie a usiloval sa o založenie slovenského cirkevného a literárneho spolku. Pešt'budínski Slováci uvažovali aj o založení nového literárneho časopisu a hl'adali osobu, ktorá by stála na jeho čele. Napokon Palárik na túto dôležitú úlohu oslovil v roku 1857 Pavla Dobšinského: „Pre naše nestále položenie $\mathrm{v}$ Pešt'-Budíne ani ja, ani Viktorin nemôžeme niečo také podniknút'. Hoci Mallý si želá, aby redaktorom tohto časopisu bol niekto z katolíckej strany, ja a Viktorin nevidíme potrebu, aby pri čisto národnom podujatí sa bral ohl'ad na náboženskú príslušnost'. Chceme mat' súceho redaktora, či už to bude katolík a či evanjelik. Ba evanjelik by nám bol ešte milší najmä preto, lebo sa môže ovel’a slobodnejšie pohybovat' než katolícky kňaz. Napokon i preto, aby sa nezdalo, že katolíci chcú slovenskú literatúru akoby monopolizovat', čo by pre náš národ mohlo mat' zhubné následky. “13 Pre nový slovenský literárny časopis bol navrhovaný „názov Sokol, Besedník či Zábavník a mal vychádzat' 2 až 3x mesačne“" (Kačírek 2016: 150), pričom najdôležitejšou podmienkou pri výbere redaktora i obsahu bola odbornost'. A hoci vo vydávaní časopisu slovenskí národovci v Budapešti neuspeli, ${ }^{14}$ vo vydavatel'ských ambíciách sa zastavit' nenechali. Pod názvom Concordia (Svornost') vydali Viktorin a Palárik v roku 1858 literárny almanach, ciel’om ktorého bolo zblížit používatel'ov spisovnej slovenčiny a staroslovenčiny ${ }^{15}$ a odstraňovat' konfesionalizmus ako prekážku v zjednotení národných a kultúrnych síl.

\section{Dráma a divadlo}

Počas pobytu $\mathrm{v}$ Budapešti sa v Palárikovi prebudila aj silná citová náklonnost' zo seminárnych čias - láska $\mathrm{k}$ dramatickému umeniu. Navštevoval peštianske divadlá, kde bol očarený „zvlášt’ umeleckou hrou slávneho herca Emila Devrienta“ (Bobula 1871: 509), venoval sa štúdiu teórie drámy a dramatického umenia, čítal diela francúzskej, nemeckej a slovanskej dramatickej literatúry a pustil sa do písania dramatických textov. Divadelné hry písal Palárik s vedomím, že vytvára repertoár pre divadlo svojej doby. Tvorbou vyzýval ku konkrétnym činom a národným aktivitám. Vysoko kládol význam divadla pre národný život, pretože si plne uvedomoval jeho spoločenský dosah. Dramatické dielo zhmotnené do javiskovej podoby považoval Palárik za najúčinnejší prostriedok k pozdvihnutiu národa, rozvoju vzdelania, videl v ňom jedinečnú možnost' na šírenie osvety a agitácie. V súvislosti s divadlom tvrdil, že ,jestli nikdá dobrých národných divadelných kusov, v ktorých sa rodinný a spoločenský život národa nášho s jeho dobrými i zlými stránkami, s cnostiami i tôňami v zajímavých a pikantných výjavoch líčit' má, Slovákom k čítaniu nepodáme: tak ani divadlo u nás nikdy nepovstane, ale ani život náš spoločenský nikdy sa v ná-

${ }^{13}$ Pozri Palárik 1857.

${ }^{14}$ Periodikum Sokol. Časopis pre krásne umenie a literatúru začalo napokon vychádzat’ v roku 1860 v Banskej Štiavnici. Časopis patril k najčítanejším periodikám. Jeho prvým redaktorom a vydavatel'om bol Pavol Dobšinský. Pod Dobšinského vedením vyšli len dva ročníky, časopis po ňom prevzal Viliam Pauliny-Tóth, ktorý ho viedol v rokoch $1862-1869$.

${ }^{15}$ Išlo o češtinu čiastočne prispôsobenú pre Slovákov. Jej pravidlá vypracoval a vydal Andrej Radlinský pod názvom Pravopis slovenský s krátkou mluvnicí (1850). V pät'desiatych rokoch 19. storočia sa v tejto reči úradovalo a v niektorých školách aj učilo. 
rodní nepreporodí, nezošlechtí.“ (Beskydov 1860: 14). Palárik pocítil ohromnú silu a možnosti divadla, jeho bezprostredné komunikačné schopnosti, ktoré vedia preklenút' aj negramotnost' l'udu a národne ho formovat'. Prvú hru, ktorú napísal, nazval Slovenský kosec (1857) a o rok neskôr ju uverejnil v almanachu Concordia pod názvom Inkognito. Druhú veselohru pod titulom Drotár publikoval v roku 1860 v almanachu Lipa a divácky i čitatel'sky najúspešnejšiu hru Zmierenie alebo Dobrodružstvo pri obžinkoch mu uverejnili opät' v almanachu Lipa v roku 1862. Historickú drámu Dimitrij Samozvanec už zverejnit' nestihol, vyšla posmrtne v jeho zobraných dramatických spisoch (Palárik, 1871).

V dramatickom písaní sa Palárik prejavil ako dramatik so značným divadelným cítením, na čom mali nemalú zásluhu aj časté návštevy divadelných predstavení peštianskych divadiel a tiež štúdium odbornej literatúry. Vo všetkých troch veselohrách vynikajúco využil staré, značne prít'ažlivé a populárne divadelné prostriedky - zámenu osôb, slovné skomoleniny, preoblečenie a nedorozumenia, ktoré z toho vyplývajú. Do tohto pôsobivého a pútavého divadelného šatu zakomponoval vlastné ideové a názorové postuláty, aj vlasteneckú a už oneskorenú obrodeneckú agitáciu. Slovenskej národnej veci, slovenskej inteligencii, ale aj l'udovým vrstvám sa usiloval naklonit' zámožných l’udí s pevným spoločensko-ekonomickým zázemím z radov meštianstva, mestských bohatých vrstiev a napokon aj z radov aristokracie. O Palárikovom vzdelaní a divadelnom rozhl'ade vel'a hovoria aj jeho teoretické práce. V teoretizujúcej stati zameranej na sociálnu funkciu drámy Dôležitost’ dramatickej národnej literatúry publikovanej v časopise Sokol v roku 1860, analyzuje význam, poslanie a spoločenské funkcie drámy a divadla, pričom v intenzite dopadov a účinkov dáva prednost' divadlu pred literatúrou. Na drámu nazerá prísne národno-obrodenecky vyzdvihuje jej výchovno-sociálnu funkciu a schopnost' ponúknut' divákovi vhodný, najmä domáci vzor, čím sa zároveň podnieti vzdelanost' národa a utvorí sa tak národná inteligencia.

Po uverejnení Palárikovej veselohry Inkognito bolo na Slovensku skutočne cítit’ „čulejšsi“‘ divadelný ruch. Najmä v kruhoch národne uvedomelej mládeže sa začínajú formovat' ochotnícke divadelné spoločnosti, ktoré inscenujú Palárikove veselohry ako prví uviedli Inkognito 24. augusta 1859 študenti z Prešova v mestečku Nemecká Lupča a vel'mi rýchlo sa objavilo aj na ochotníckych javiskách mnohých slovenských miest a mestečiek (v roku 1859 v Banskej Bystrici hru pripravovali študenti alumnea, ale predstavenie bolo pre jeho obsah zakázané; v roku 1859 uviedli hru v Martine a Ratkovej a neskôr tiež v Pribyline, Tisovci, Trenčíne, Trnave, Lubietovej, Liptovskom Mikuláši a na d'alších ochotníckych javiskách). ${ }^{16}$ Možno povedat', že Palárikove veselohry zaplavili slovenské ochotnícke scény a ochotníci nimi často otvárali divadelnú sezónu alebo miestne ochotnícke divadlo. Palárik hrami potvrdil, že na prebudenie národného života nič nepôsobí tak intenzívne a zdarne, ako národná dramatická literatúra a divadlo.

\section{Srbské národné divadlo a Palárikovo Inkognito}

${ }^{16}$ Podrobne o uvádzaní Palárikových hier na slovenských profesionálnych a ochotníckych javiskách pozri v publikácii Palárik žije. Súborné dramatické dielo Jána Palárika (2017) editora a autora Martina Timka. V závere publikácie podáva Timko komplexný prehl’ad inscenačnej tradície Palárikových hier v slovenských profesionálnych divadlách a tiež súpis uvádzania hier na ochotníckych javiskách do roku 1920 na Slovensku. 
Problematika národného odrodilstva a satirické stvárnenie falošnosti l’udských charakterov i spoločenského života zobrazené v Palárikovom Inkognite nepochybne zaujali nielen Slovákov, ale aj iné slovanské národy žijúce v mnohonárodnostnej habsburskej monarchii, pretože dielo zhmotňovalo ich národné cítenie a pozorovali v ňom aj vlastné osudy. Veselohrou Inkognito (1858) nadviazal Palárik na Kocúrkovo Jána Chalupku a oživil pestrú paletu kocúrkovských postáv. Kým Chalupka vytváral vo svojich hrách dva krajné póly postáv a ich charaktery sa v priebehu hry nemenili, Palárik vsúva medzi dobré a zlé postavy ešte hrdinu, o ktorého sa v hre „bojuje” - často idealizovaného hrdinu, národovca ako protiklad k malomestskému odrodilcovi. Charakter týchto hrdinov nie je vopred daný, mení sa v priebehu hry, ide o to, na ktorú stranu sa postava prikloní (v Inkognite sú to vdova Sokolová a jej dcéra Evička - na začiatku hry odnárodnená Everlin sa postupne mení pod vplyvom národovca Jelenského na slovenskú Evičku Sokolovú). Komiku a napätie v hre Inkognito vystaval Palárik na zámene mien a osôb a hoci zápletku prevzal z francúzskej hry, postavy a prostredie sú originálne a vychádzajú zo slovenskej reality. Palárik sa hrami usiloval o získanie bohatších vrstiev spoločnosti na podporu emancipačných snáh Slovákov, a preto do veselohier umiestňoval postavu, o ktorú sa „bojuje”, čím vyjadroval svoje politické názory a spoločenské tendencie.

A práve Palárikovu veselohru Inkognito uviedli v Budapešti srbskí vlastenci v rámci jednej zo „slovanských zábav“, ako sa v 19. storočí nazývali divadelno-tanečné spoločenské stretnutia. V dome bohatého obchodníka, statkára a úradníka Josipa Stankovića-Duku, brata známeho srbského hudobného skladatel'a Kornelijea Stankovića, sa začiatkom roka 1861 sformoval umelecký súbor pod názvom Dobrovol'nícka divadelná spoločnost' v Budíne (Dobrovoljačko pozorišno društvo u Budimu; na niektorých plagátoch uvádzané aj ako Dobrovoljno pozorišno društvo) ako srbská amatérska divadelná spoločnost' (Марјановић 2011: 25). Ciel'om divadelnej spoločnosti bolo propagovat' ideu založenia srbského profesionálneho divadla a získavat' peňažné prostriedky pre budúce národné divadlo. Srbskí vlastenci - obchodníci, úradníci, vzdelanci - žijúci v Pešti a Budíne a najmä študenti zoskupení okolo Tekeliana ${ }^{17}$ vnímali divadlo ako dôležitú národnú ustanovizeň, prostredníctvom ktorej môžu podporovat' národné sebavedomie a bojovat' za národné práva. Uvedomovali si potrebu vzniku profesionálneho divadla v materskej krajine a preto sa rozhodli podporit' jeho vznik najmä finančnými prostriedkami. Na tento účel im slúžili výt’ažky z predstavení uvádzaných v dome Stankovića. Podrobný opis srbských predstavení uvedených v záhrade Stankovićovcov v Budíne v roku 1861 podáva v štúdii „Културна збивања међу Србима у Пешти и Будиму 1860-1861. И њихове позоришне представе II-III“" (Kultúrne udalosti medzi Srbmi v Pešti a v Budine 1860 - 1861. A ich divadelné predstavenia II - III) divadelný historik Božidar Kovaček (Ковачек 2003), ktorý zrekonštruoval chronológiu predstavení, repertoár, venoval sa spôsobu inscenovania jednotlivých textov, podal detailné životopisy interpretov a upozornil tiež na zaujímavé spoločné kultúrno-vzdelávacie aktivity Srbov a Slovákov pôsobiacich v tom období v Budíne a v Pešti.

${ }^{17}$ Tekelianum (Collegium Tökölyanum) - vzdelávacia ustanovizeň a nadácia, ktorú v roku 1838 založil v Pešti právnik a mecenáš Sava Popović Tekelija (1761 - 1842) s ciel’om, aby v nej mohli študovat' chudobní a najlepší srbskí žiaci a študenti pochádzajúci z krajov, kde žili Srbi. 
V záhrade Stankovićovcov postavili v roku 1861 divadelnú dvoranu, takzvané letné javisko, na ktorom postupne inscenovali pät' dramatických textov (tri srbské komédie, jednu veselohru neznámeho nemeckého autora a Palárikovo Inkognito), ktoré uviedli v ôsmich predstaveniach. O predstaveniach budínskeho amatérskeho divadla informovali ručne písané plagáty, z ktorých sa môžeme dozvediet' nielen názov hry, meno autora a obsadenie, ale bola na nich uvedená aj cena vstupného a zároveň informácia o možnosti dobrovol'ných príspevkov na novovznikajúce Srbské národné divadlo v Novom Sade. (Ковачек 2003: 44) Zo vstupného sa hradili výdavky na divadelné produkcie u Stankovićovcov a všetky ostatné príspevky šli na divadlo do Nového Sadu.

Inscenovanie slovenskej hry v srbskom preklade v dome Stankovićovcov možno zaradit' k nepochybne zaujímavým a výnimočným počinom srbských vlastencov, ktorí siahli po diele vtedy ešte neznámeho slovanského autora. Palárik sa v kruhoch pešt'budínskych slovanských intelektuálov, podnikatel'ov, literátov, študentov a vlastencov síce obratne pohyboval, avšak o jeho dramatických aktivitách, ktoré navyše publikoval pod pseudonymom Beskydov, tušil len málokto. Dokonca len vd'aka uvedeniu Inkognita v Budapešti a vyvolaniu autora na javisko sa auditórium a neskôr aj literárna a divadelná verejnost' dozvedeli, kto sa za menom Beskydov skutočne ukrýva. Na tomto mieste však treba uviest', že Palárikove kontakty so Srbmi sa nezačali až uvedením jeho Inkognita v dvorane Stankovićovcov, ale o niekol'ko rokov skôr, počas početných stretnutí s predstavitel'mi Matice srbskej a s redaktormi časopisu Letopis Matice srbskej. Spolu s Jozefom Viktorinom sa 12. januára 1858 stretli s vtedajším tajomníkom Matice srbskej a neskorším riaditel'om Srbského národného divadla v Novom Sade, Jovanom Đorđevićom, a práve Đorđević zoznámil svojho nasledovníka Antonija Hadžića ${ }^{18}$ so slovenskými kn̆azmi a redaktormi. (Ковачек 2003: 42) O tri roky neskôr nachádzame už Hadžića v dome Josipa Stankovića v úlohe iniciátora a organizátora divadelných podujatí. On bol dušou amatérskej divadelnej spoločnosti, niekedy dokonca ako najstarší a najskúsenejší aj režíroval, a ked' bolo potrebné, zhostil sa malých hereckých rolí. V roku 1861 práve Hadzić „upozornil na Palárikove diela svojho chránenca Kostu Ruvaraca“ (Ковачек 2003: 42), ktorý Palárikovo Inkognito upravil pre potreby srbských divadelníkov.

V pät'desiatych a šest'desiatych rokoch 19. storočia sa v Budapešti divadelníctvo rozvíjalo v značnej miere. Dlhoročnú tradíciu a viacero kamenných scén malo v meste nemecké a mad'arské divadelníctvo a z nemad'arských národov boli „najaktívnejší miestni Srbi““. (Kačírek 2016: 210) V dome bohatého srbského obchodníka a vlastenca Stankovića usporadúvali pešt’budínski Srbi spoločenské stretnutia, ktoré mali charakter národných podujatí a boli spojené s uvádzaním divadelných hier. Ako sme už spomínali, v roku 1861 videli diváci v záhrade Stankovićovcov dovedna osem predstavení, medzi nimi aj Palárikovu hru Inkognito, ktorú srbskí amatérski divadelníci uviedli dvakrát (hra mala premiéru 11./23. 6. $1861^{19}$ a repríza sa konala 25. 6./7. 7. 1861). Z reprízy inscenácie sa zachoval dokonca plagát, vd’aka ktorému poznáme

${ }^{18}$ Antonije Tona Hadžić (1831 - 1916) - v rokoch 1859 - 1895 bol tajomníkom Matice srbskej, neskôr sa stal jej predsedom; pôsobil ako redaktor časopisu Letopis Matice srbskej; počas pobytu v Budapešti organizoval spolu s Lazom Kostićom predstavenia na podporu Srbského národného divadla v Novom Sade a stál pri zrode Dobrovol'níckej divadelnej spoločnosti; pôsobil ako dramaturg, režisér a riaditel' Srbského národného divadla v Novom Sade.

${ }^{19} 11$. júna 1861 - podl’a juliánskeho kalendára. 
celkové obsadenie, miesto, dátum a čas konania a tiež aj cenu vstupeniek a požiadavku na dobrovol'né príspevky pre profesionálne divadlo. (Ковачек 2003: 40)

Dopisovatel' novín Pešt'budínske vedomosti podpísaný skratkou J. A. P. o tomto spoločensko-kultúrnom stretnutí podal pomerne obsiahlu správu, z ktorej sa dozvedáme nielen o samotnom priebehu slovanskej zábavy, ale aj o zámeroch jej usporiadania, o prijatí hry Inkognito obecenstvom a tiež o „odhalení“ totožnosti dramatika. Výnimočné podujatie sa konalo v záhrade Josipa Stankovića od piatej hodiny popoludní 23. júna 1861 a zišlo sa na ňom „početné mužské obecenstvo záležiace zo Srbov a Slovákov (...) a hra sa pod holým nebom - teda v aréne - srbskými zástavami a národnými barvami ozdobených miestnosti započala." (J. A. P. 1861:2) Na divadelnú zábavu boli pozvaní najmä Slovania žijúci v Budapešti, pretože výt’ažok z podujatia bol venovaný na formujúce sa Srbské národné divadlo v Novom Sade ${ }^{20}$ : „Jako je známo, má sa v Novom Sade národnie srbské divadlo založit', ku ktorému ciel’u v krajoch srbských dobrovol’né sbierky a príspevky sa usporadujú (...) aby sa nie len Srbom, ale i druhým tutejším Slavianom na oltár osvety národnej peňažite prispiet' príležitost' zavdala." (J. A. P. 1861: 4) Srbskí ochotnícki herci - predovšetkým členovia rodiny Stanković-Duka ${ }^{21}$ - naštudovali Palárikovo Inkognito v srbskom preklade či skôr v „posrbčení“ vtedajšieho študenta práva, spisovatel’a Kostu Ruvaraca ${ }^{22}$, kto-

${ }^{20}$ Prvá profesionálna divadelná skupina v Srbsku bola založená v roku 1838, v Novom Sade. Išlo o „Leteće diletantsko pozorište“, ktoré do roku 1840 hrávalo v Novom Sade, Zemune a v Pančeve; od júna 1840 do roku 1841 hrávalo v Záhrebe (pod názvom Domorodno teatralno društvo) a napokon v roku 1842 sa členovia tohto divadla stali súčast'ou už existujúceho belehradského Divadla pri colnici (Teatar na Đumruku) - prvého profesionálneho divadla v Belehrade. Práve spomínaní novosadskí divadelníci a národovci mali najväčšiu zásluhu na tom, že v šest'desiatych rokoch 19. storočia sa u južných Slovanov formujú prvé stále profesionálne divadelné súbory (Nový Sad - 1861, Záhreb - 1861, Belehrad - 1868). Srbské národné divadlo (Srpsko narodno pozorište) bolo osnované 28. júla 1861 v Novom Sade na zasadnutí Srbskej čitárne (Srpska čitaonica), ktorej predsedal Svetozar Miletić, ako národná ustanovizeň, ciel'om ktorej bolo pozdvihovat' kultúrnu úroveň Srbov, povzbudzovat' národné povedomie a prostredníctvom dramatického a hereckého umenia prenášat' z javiska srbský jazyk a srbskú históriu divákom. Podrobne o zakladaní a vzniku profesionálnych divadiel u južných Slovanov a o histórii Srbského národného divadla v Novom Sade pozri napríklad v textoch: Stojković 1979; Марјановић 2011; Максимовић 2012.

${ }^{21}$ Hlavnú úlohu bohatej vdovy po kocúrkovskom richtárovi, pani Sokolovú stvárnila Pava (Paulina) Stankovićová (Sokolovička); jej dcéru Evičku hrala Mara Dukina (Evica); slúžku Sokolovej Borku, Ruvaracom premenovanú na Martu, zahrala Pava (Paulina) Dukina; radného pána z Kocúrkova (Ruvarac zmenil názov mestečka na Krstovo), pána Potomského, stvárnil Đorđe Maksimović; jeho syna Jána Jelenfyho (u Ruvaraca Milan Jelenfi) zahral Mita Krestić a úlohy básnika Jána Jelenského sa zhostil organizátor predstavenia Antonije Hadžić. Len pre zaujímavost doplníme, že malú úlohu úradníka si zahral jeden z najznámejších srbských básnikov Laza Kostić. Podrobne o obsadení pozri Ковачек 2003: 40.

${ }^{22}$ Kosta Ruvarac (1837 - 1864) - brat významných srbských historikov Ilariona a Dimitrija Ruvaracových; srbský literárny kritik, literát a blízky priatel' Lazu Kostića; bol zakladatel’om a najaktívnejším členom srbskej peštianskej literárnej skupiny „Preodnica“ (po slovensky Dennica alebo Zornička); v Budapešti študoval právo, literatúru a estetiku (dizertačnú prácu obhájil v januári 1864); zaujímal sa o rôzne literárne žánre - písal prózu (Karlovacký žiak, 1862), etnografické štúdie a literárne kritiky; mal značný podiel na budovaní a formovaní srbského národného divadla - stál pri zrode srbského amatérskeho divadla v Budapešti, do srbčiny preložil sedem dramatických textov, ako herec účinkoval v predstaveniach usporadúvaných v Budapešti v dome Josipa Stankovića a venoval sa teórii drámy (je autorom kritiky na drámu s historicko-národnou tematikou 
rý si v predstavení dokonca zahral postavu učitel'a Starosvetského (u Ruvaraca to bol učitel' Zdravković). Na margo prekladu treba dodat', že dopisovatel' a zároveň priamy účastník podujatia J. A. P. hodnotil preklad ako „dobrý“ a to, čo v pôvodnom texte sa „na živel slovenský vst'ahuje, prekladatel’ so živlom srbským do súzvuku prepracoval“" a za preklad si nepochybne zaslúži pochvalu. (J. A. P. 1861: 2)

Vd'aka Ruvaracovmu prekladu ${ }^{23}$ ale aj tendenciám, ktorú veselohra zastupovala, sa Palárikovo Inkognito dostalo aj na javiská srbských divadiel - hru si vypýtal Jovan Đorđević ${ }^{24}$, aby ju mohli uviest' na scéne Srbského národného divadla v Novom Sade. Žial', o uvedení Inkognita v Srbskom národnom divadle vieme len vel'mi málo. Archív Srbského národného divadla v Novom Sade nám neponúka dobové plagáty, a tak na základe ohlasov a recenzií v dobovej tlači môžeme zrekonštruovat' len obsadenie a počet repríz. ${ }^{25}$ Palárikovo Inkognito malo v divadle premiéru 29. augusta 1862 a dožilo sa desiatich repríz. V roku 1867 ho inscenátori zo Srbského národného divadla uviedli aj vo Vel'kom Bečkereku (dnešný Zrenjanin), kde Inkognito zaznamenalo pät' repríz. Hra mala medzi srbskými divákmi dobrú odozvu najmä preto, lebo akcentovala tendencie srbského národa postavit' sa proti mad'arizácii a reflektovala národno-politické úsilia vtedajšieho Srbského národného divadla. Na uvedení hry záležalo najmä zakladatel'ovi a riaditel'ovi divadla Jovanovi Đorđevićovi, o čom svedčí aj Đorđevićov záujem o dobrý preklad hry, ked' pôvodný preklad až trikrát vrátil Ruvaracovi s tým, že by bolo vhodné text Inkognita viac inkorporovat' na srbské pomery. (Ковачек 1973) Đorđević v liste Hadžićovi napísal, že ak by sa z „Potomského a Jelenfyho urobili srbskí mad’aróni““ (Ковачек 2003: 44), mohla by sa hra inscenovat' aj v Srbskom národnom divadle. ${ }^{26}$

\section{Herceg Vladislav Jovana Subotića).}

${ }^{23}$ Kosta Ruvarac pripravil preklad - „posrbčenie“ Inkognita v roku 1861 pre Dobrovol'nícku divadelnú spoločnost' v Budíne. Zapálenost'ou a angažovanost'ou v amatérskej divadelnej spoločnosti i vo formujúcom sa národnom divadle zastával Ruvarac miesto jedného z najvýznamnejších podporovatel'ov myšlienky divadla ako národnej inštitúcie.

${ }^{24}$ Jovan Đorđević (1826 - 1900) - srbský literát, zakladatel’ srbských divadiel; iniciátor myšlienky založenia Srbského národného divadla; bol prvým riaditel'om Srbského národného divadla (1861 1867), dramaturgom, zostavovatel'om repertoáru, prekladatel'om i režisérom; na pozvanie srbského kniežat’a Mihaila Obrenovića odišiel v roku 1867 s čast'ou novosadského ansámblu host'ovat' do Belehradu, kde založil Národné divadlo a od roku 1868 pôsobil ako jeho riaditel'. Đorđević presadzoval myšlienku, že bez vlastnej kultúry a autochtónneho jazyka sa moderný národ nemôže zjednotit' a konštruovat' a práve tomuto ciel'u najefektívnejšie slúži národné divadlo.

${ }^{25}$ Podrobne o uvedení Inkognita v Srbskom národnom divadle v Novom Sade a Vo Vel'kom Bečkereku pozri v encyklopédii Srbského národného divadla (ЕCHП).

${ }^{26}$ Archívny výskum Dr. Božidara Kovačeka dokumentuje, že Ruvarac na naliehanie Đorđevića takmer rok pracoval na novom preklade Inkognita. Súhlasil, že Palárikov text ešte viac „,posrbčí“ a preklad prepracuje podl'a inštrukcií. Đorđević vrátil Ruvaracovi preklad trikrát a ten ho na štvrtý raz poslal Đorđevićovi so slovami, že teraz ,je v ňom t'ažko niečo zo slovenského nájst'.“ (Ковачек 2003: 44). O osudoch jednotlivých verzií prekladu nemáme žiadne informácie. V zobraných spisoch Kostu Ruvaraca (Поповић 1866) sa preklad Inkognita nenachádza, nemôžeme teda prvotnú či jednu z d'alších verzií porovnat' s originálom v zmysle miery „posrbčenia“ textu v oblasti lexiky či reálií. Ruvaracov preklad Inkognita vyšiel neskôr spolu s inými „posrbčenými“ dramatickými textami v piatom zväzku Srbská literatúra - Dráma pod redakciou Petara Marjanovića (Марјановић 1987). 
Na predstavení Inkognita v dome Stankovićovcov bol prítomný aj Ján Palárik, ktorého obecenstvo už po druhom dejstve vyvolávalo na scénu. Na konci predstavenia za hlučného a hromového „Živili“ a „Sláva“ vystúpil Palárik na pódium, kde mu Mara Dukina (stvárnila úlohu Evičky) veniec „,s trikolorom slavianskym doručila a ho tým pred obličajom nebies a obecenstva k d'alším dramatickým dielam vyzvala.“ (J. A. P. 1861: 2) Za hromového živio sa Palárik herečkám pod’akoval a dojatým hlasom povedal: „Nech žijú Srbi, nech žijú Slovania.“ (Ковачек 2003: 45) Pre Palárika to bolo skutočne výnimočné podujatie, ved” po prvý raz videl realizáciu vlastnej hry na javisku, a tak prvé verejné ovácie a uznanie dostali sa mu „nie od svojich vlastných rodákov, lež od spolukmenovcov Srbov.“ (J. A. P. 1861: 2) A hoci malo predstavenie súkromný charakter, zišlo sa na ňom množstvo národovcov, medzi ktorými nechýbali slovenskí spisovatelia, srbskí vlastenci a žiaden „kmen slaviansky“, ktorí hru prijali s nadšením a ováciami tak, že ,potleskom a vyvolávaniu nebolo konca kraja a perá kvetov (kytice, bukrety) len tak pršaly na javište“ ${ }^{27} \mathrm{Až}$ do uvedenia Inkognita u Stankovićovcov len málokto okrem Palárikovych priatel'ov vedel, kto je autorom úspešných veselohier. Identita Beskydova vyšla teda najavo až počas pešt'budínskeho predstavenia hry Inkognito, ked' dvaja srbskí právnici vyvolali Palárika na javisko, hoci on chcel zostat' utajený medzi obecenstvom. Takto sa aj slovenskí čitatelia a ochotnícka mládež dozvedeli, že autorom oblúbených divadelných veselohier Inkognito a Drotár je slovenský katolícky kňaz Ján Palárik.

Kontinuálne priatel'ské vzt’ahy a spolupráca medzi Slovákmi a Srbmi v Budapešti sa uvedením Palárikovho Inkognita v záhrade Stankovićovcov neskončili. Rozvíjali sa intenzívnejšie a pravidelnejšie, a to nielen pri sledovaní divadelných predstavení, ale aj pri spoločných stretnutiach. Len niekol'ko dní po premiére Inkognita zavítala do Budapešti slovenská delegácia vedená Jánom Franciscim, aby odovzdala Memorandum národa slovenského podpredsedovi uhorského snemu Kalmánovi Tiszovi. Po odovzdaní dokumentu sa členovia delegácie (Jozef Miloslav Hurban, Štefan Marko Daxner, Ján Francisci a Viliam Pauliny Tóth) spolu s manželkami posledných dvoch menovaných, vybrali na Margitin ostrov, aby si po náročnom dni oddýchli. Ako sa približovali k brehom ostrova, začuli „čarovné zvuky tamburice srbskej“ (Budín 1. Jula 1861) a len čo vystúpili, ocitli sa v obkl’účení srbskej mládeže. Nasledovali spoločné piesne a tance, zdravice a príhovory. Prítomných po srbsky pozdravil Jozef Miloslav Hurban a odpoved' v srbčine predniesol Kosta Ruvarac. Ako uvádza dopisovatel' Pešt'budinskych vedomostí, išlo o náhodné stretnutie a nie všetci jeho účastníci sa predtým poznali, avšak „bližšiu osobnú známost’ vynahradzovala osobná bratrská láska a vzajemnost' slavianska.“ (Budín 1. Jula 1861) O tri dni neskôr, 30. júna 1861, sa Slováci a Srbi opät’ stretli v dome Stankovićovcov, aby

${ }^{27}$ Citované z listu, ktorý o predstavení Inkognito v Budapešti napísal a do redakcie časopisu Sokol zaslal advokát a politik Ludovít Turzo-Nosický. Priam emotívne opísal herecké umenie i kostýmy, nadšený bol najmä krásou a hereckými výkonmi mladých Srbiek: „Ty utešené Srbskyne nikdy som ešte $\mathrm{v}$ tak početnom kole a tak krásne nevidel. Ten národný kroj, ty serbianky modré a oplecká s bielymi rukávmi - ach, ako malebne vypadaly na švihl'ých driečkoch a okrúhlych, snehobielych ramenách nositel'kýň svojich! A ty tu i tu zádumčivé tu i tu veselé, vždy ale nežné a nevýslovne milé t’ahy prekrásnych tváričiek - darmo sa namáham opisovat'. Kdo si chceš predstavit' Srbkyňu, idz ta, kde ju možno kvitnúcu v národnom odeve vidiet' a pochopíš tak ako ja; opísat' ju nebudeš moct', oj, ale na milý dojem, pod ktorým vzdýchne srdce tvoje, nezabudneš nikdy.“ Podrobne pozri článok $Z$ Budina 1861. 
si pozreli reprízu veselohier Kobno ime (Osudné meno) a Tvrdica (Skupáň), z ktorých prevedenia bol autor článku nadšený a vysoko vyzdvihol najmä herecké výkony Pavy Stankovićovej a Mary Dukovej: „Tie potlesky, ktoré sa skončit' nechcely, tie početné vyvolávania, tie vence a kvety, ktoré na javište lietaly, vydávajú dostatočné svedectvo, jak o dobrom prevedení kusov, tak aj o vytržení tom, do jakého obecenstvo prišlo.“ (Budín 1. Jula 1861) Po predstavení nasledovali spoločné piesne srbské i slovenské pri tamburiciach a tancovalo sa srbské kolo. Okrem chvál na predstavenie („A nebolo brata, ktorý by sa v tomto kole bratov srbských pri tak ušlechtilom národnom pôžitku duše, nebol cítil blaženým.") a podpory slovanskej vzájomnosti autor článku v závere pripomína, že výtažok z predstavenia „na srbské divadlo novosadské obetovaný je.“ (Budín 1. Jula 1861) Aj touto účast'ou na predstavení srbských veselohier prispeli slovenskí národovci k vzniku a rozvoju srbského profesionálneho divadla.

Uvedenie Inkognita srbskými vlastencami malo pre Palárika mimoriadny význam. Po prvý raz videl na javisku vlastnú hru, prezradila sa jeho identita ako dramatika, no najmä, potvrdili sa jeho idey o slovanskej vzájomnosti a spolupráci medzi slovanskými národmi. Navyše, hra našla svoje miesto aj na srbských javiskách a jej nosné myšlienky postupne prenikali medzi Slovanov na Balkáne. Slovanské obecenstvo nesporne videlo v Inkognite osoby a výjavy z ,vlastného“ života, počulo súdobé názory na spoločnost' i politiku, vnímalo predsudky aj možnú nápravu l'udského charakteru. Hra oplýva humorom, komickými situáciami, reálnym jazykom (jazyk je často hrubý až farsovitý), pravdivost'ou a najmä, ukazuje aj dramatikovu znalost' divadelného javiska. Všedná situačná veselohra postavená na princípe dvojníctva (zámeny postáv) popretkávaná národnými a sociálnymi motívmi bola nepochybne tou najlepšou vol'bou pre podujatie, na ktorom sa v júni 1861 vyberali peňažné prostriedky pre založenie a fungovanie Srbského národného divadla.

\section{Citovaná literatúra}

Beskydov, Ján. „Dôležitost’ dramatickej národnej literatúry“. Sokol. Časopis pre krásno umenie a literatúru1(2), 1860: 13-14; 1(3), 1860: 21-23.

Bobula, Ján Nepomuk. „Za osvetu“. [In:] Sobrané dramatické spisy Jána Palárika, (Beskydova) slavného spisovatel'a slovenského. 2. zv. Pešt': Minerva, 1871: 501-518.

„Budín 1. Jula“. Pešt'budínske vedomosti 1(32), 5.7.1861: 2-3.

J. A. P. „Budín 24. Juna“. Pešt'budínske vedomosti 1(30), 28. 6. 1861: 2.

Kačírek, Luuboš. Národný život Slovákov v Peštbudíne v rokoch 1850 - 1875. Békescsaba:

Magyarországi Szlovákok Kutatóintézete/Výskumný ústav Slovákov v Mad’arsku; Kor/ ridor Könyvek - Kor/ridor Knihy, 2016.

Palárik, Ján. Ján Palárik Pavlovi Dobšinskému (list). Pešt' 18. 10. 1857. [In:] LA SNK, sg. A 1158.

Palárik, Ján. , Jednota w Církwi “. Cyrill a Method 1(16), 1850.

Palárik. Ján. O vzájomnosti slovanskej. Zlatý fond denníka SME, 2012. <http://zlatyfond.sme. sk/dielo/1757/Palarik_O-vzajomnosti-slovanskej> 29.04.2021

Palárik, Ján. Sobrané dramatické spisy Jána Palárika, (Beskydova) slavného spisovatel’a slovenského 1. zv. Pešt': Minerva, 1870.

Palárik, Ján. Sobrané dramatické spisy Jána Palárika, (Beskydova) slavného spisovatel’a 
slovenského 2. zv. Pešt': Minerva, 1871.

Stojković, Borivoje. Istorija srpskog pozorišta od srednjeg veka do modernog doba (drama i opera). Beograd: Muzej pozorišne umetnosti Srbije, 1979.

Timko, Martin (red.). Palárik žije. Súborné dramatické dielo Jána Palárika. Raková: Životnými cestami Jána Palárika - združenie, 2017.

„Z Budína. (Hra Incognito)“. Sokol 2/19, 1861: 151-152.

ЕСНП: Енциклопедија Српског народног позоришта < https://www.snp.org.rs/ enciklopedija/?p=4872> 28.06.2021.

[ESNP: Enciklopedija Srpskog narodnog pozorišta $<$ https://www.snp.org.rs/ enciklopedija/?p=4872> 28.06.2021]

Ковачек, Божидар. „Културна збивања међу Србима у Пешти и Будиму 1860-1861. И њихове позоришне представе II-III“،. Зборник Матице српске за сценске уметности и музику 28-29, 2003: 29-91.

[Kovaček, Božidar. „Kulturna zbivanja među Srbima u Pešti i Budimu 1860-1861. I njihove pozorišne predstave II-III“. Zbornik Matice srpske za scenske umetnosti i muziku 28-29, 2003: 29-91]

Ковачек, Божидар. Преписка између Јована Ђорђевића и Антонија Хаџића (1859-1895). Нови Сад: Српско народно позориште, 1973.

[Kovaček, Božidar. Prepiska između Jovana Đorđevića i Antonija Hadžića (1859-1895). Novi Sad: Srpsko narodno pozorište, 1973]

Максимовић, Зоран. „Сто педесет година Српског народног позоришта“. Свеске Матице српске: грађа и прилози за културну и друштвену историју 14, 2012: 7-12.

[Maksimović, Zoran. „Sto pedeset godina Srpskog narodnog pozorišta“. Sveske Matice srpske: građa i prilozi za kulturnu i društvenu istoriju 14, 2012: 7-12]

Марјановић, Петар. „Оснивање и рад Српског народног позоришта у Новом Саду (18611914)“. Зборник Матице српске за сценске уметности и музику 45, 2011: 23-51.

[Marjanović, Petar. „Osnivanje i rad Srpskog narodnog pozorišta u Novom Sadu (18611914)“. Zbornik Matice srpske za scenske umetnosti i muziku 45, 2011: 23-51]

Марјановић, Петар (прир.). Посрбе. Београд: Нолит, 1987.

[Marjanović, Petar (prir.). Posrbe. Beograd: Nolit, 1987]

Поповић, Ђорђе (прир.). Скупљени списи Косте Руварца. Део 1. Нови Сад: Издао Ђ. Поповић, 1866.

[Popović, Đorđe (prir.). Skupljeni spisi Koste Ruvarca. Deo 1. Novi Sad: Izdao Đ. Popović, 1866] 
Јулијана Бењова

\title{
УНИВЕРЗАЛНОСТ И ЈЕДИНСТВЕНОСТ ПАЛАРИКОВОГ ДЕЛА INKOGNITO (ИНКОГНИТО) У КОНТЕКСТУ ОСНИВАЬА СРПСКОГ НАРОДНОГ ПОЗОРИШТА
}

\begin{abstract}
Резиме
Активности и уметничка дела словачког католичког свештеника, уредника, драмског писца и организатора друштвеног и политичког живота Јана Паларика, у другој половини 19. века премашили су хоризонте Хабзбуршке монархије. Књижевне и друштвено-политичке трагове Палариковог деловања налазимо и међу Србима који живе у Будимпешти а који су 1861. године изабрали Паларикову комедију Инкогнито као једну од могућности за прикупљање финансијских средстава за функционисање Српског народног позоришта у Новом Саду, које је било у процесу оснивања. То што Инкогнито изводе српски родољуби било је за Паларика од посебног значаја. Први пут је на сцени видео сопствену представу, чак је разоткривен и његов идентитет као драмског писца када је публика током представе сазнала да се иза псеудонима Бескидов (Beskydov) крије будимпештански свештеник Паларик, али пре свега - биле су потврђене његове идеје о словенској узајамности и сарадњи између словенских народа. Поред тога, комад је нашао своје место и на српским сценама и његове главне идеје постепено су продирале међу Словене на Балкану. Мађарски патриота и словачки националиста далеко је прекорачио средину из које је потекао и својим следбеницима је оставио значајно наслеђе на пољу организовања националног и књижевног живота, драмске уметности и демократизујућих реформи у цркви.
\end{abstract}

Кључне речи: католички свештеник и драмски писац Јан Паларик, комедија Инкогнито, српски аматерски глумци изводе комедију Инкогнито у Будимпешти, Српско народно позориште у Новом Саду, словенска узајамност. 